\title{
ANALISIS PENDAPATAN USAHA PETERNAKAN SAPI PERAH LAKTASI \\ (Studi Kasus Di Desa Minggirsari Kecamatan Kanigoro Kabupaten Blitar)
}

\author{
Mohamad Ernawan ${ }^{1}$,Eddi Trijana ${ }^{2}$ dan Rofiq Ghozali ${ }^{3}$ \\ Mahasiswa Universitas Islam Balitar ${ }^{1}$, Staf Pengajar Universitas Islam Balitar ${ }^{2}$, \\ Staf Pengajar SMK Kademangan ${ }^{3}$ \\ Email : rofiq ghozali@yahoo.co.id
}

\begin{abstract}
ABSTRAK
Penelitian bertujuan untuk mengetahui pengeluaran atau biaya-biaya yang dikeluarkan dalam usaha peternakan sapi perah laktasi, mengetahui penerimaan dalam usaha peternakan sapi perah laktasi dan mengetahui pendapatan usaha peternakan sapi perah laktasi.Hasil yang diperoleh dari kegiatan penelitian ini adalah biaya total pada usaha peternakan sapi perah laktasi di Desa Minggirsari yaitu sebesar Rp. 52.934.600/tahun terdiri dari biaya tetap sebesar Rp. 8.141.100/tahun dan biaya variabel sebesar Rp. 44.793.500/tahun. Total penerimaan pada usaha peternakan sapi perah laktasi Di Desa Minggirsari yaitu sebesar Rp. 56.069.700/tahun terdiri dari penjualan susu sebesar Rp. 45.864.700/tahun, penjualan pedet sebesar Rp. 5.233.300/tahun, dan penjualan sapi afkir sebesar Rp. 3.925.000, dan penjualan limbah sebesar Rp. 1.046.700/tahun. Keuntungan usaha peternakan sapi perah laktasi di Desa Minggirsari sebesar Rp. 3.135.000/tahun. Berdasarkan hasil penelitian ini disarankan : sebaiknya peternak melakukan analisis pendapatan dengan teliti agar dapat mengetahui jumlh pendapatan bersih yang diperoleh, sebaiknya peternak meningkatkan jumlah sapi perah laktasi yang dipelihara sehingga keutungan yang diperoleh lebih besar, dan sebaiknya pemerintah membatasi impor susu sapi sehingga kesejahteraan pelaku usaha peternakan sapi perah meningkat.
\end{abstract}

Kata kunci : Sapi perah, analisa pendapatan

\section{PENDAHULUAN}

Usaha peternakan sapi perah merupakan usaha yang berpeluang untuk berkembang. Hal ini cukup beralasan karena kebutuhan susu di Indonesia sebagian besar dipenuhi dari impor dan konsumsi susu nasional dari tahun ke tahun terus meningkat meskipun lebih rendah bila dibandingkan dengan negara-negara ASEAN lainya. Menurut Nugroho (2011), dari data internal Tetra Pak 2010 memperlihatkan, tingkat konsumsi susu Indonesia baru mencapai 11,8 liter. Angka ini terbilang paling rendah di antara negara 
ASEAN. Contohnya negara Filipina, Vietnam, Singapura, dan Malaysia masing-masing $12,4,14,47,3$, dan 50,3 liter per kapita per tahun.

Meski konsumsi susu dalam negeri rendah, Indonesia masih mengimpor $74 \%$ dari kebutuhan susu di dalam negeri. Saat ini produksi susu nasional hanya 536.900 ton per tahun atau 26\% dari total kebutuhan dalam negeri. Pemerintah menargetkan dapat mendongkrak konsumsi susu nasional sampai 27-30 liter/kapita/tahun. Selain mendorong konsumsi susu nasional, pemerintah juga berupaya menaikkan produksi dalam negeri (Nugroho, 2010).

Sebagian besar peternakan di Indonesia merupakan peternakan rakyat yang menggunakan teknologi tradisional (Muharlien, dkk, 2008). Peluang inilah yang perlu dicermati peternak dalam usaha meningkatkan produksi susu dalam negeri yang dicanangkan pemerintah. Susu sapi merupakan bahan pangan yang sangat berharga karena memiliki kandungan nutrient esensial yang tinggi, dan menurut penelitian, dengan mengkonsumsi susu, resiko terkena penyakit degenerative menjadi rendah. Rendahnya konsumsi protein hewani berdampak pada tingkat kualitas hidup dan daya saing bangsa. Rendahnya produksi susu disebabkan oleh beberapa faktor penentu dalam usaha peternakan yaitu pemuliaan dan reproduksi, penyediaan dan pemberian pakan, pemeliharaan ternak, penyediaan sarana dan prasarana serta pencegahan penyakit dan pengobatan (Tofa, 2010).

Harga susu sapi ditingkat peternak saat ini masih rendah sekitar Rp 3.250-Rp 3.450 per liter dan meningkatnya biaya-biaya produksi membuat nasib peternak menjadi semakin sulit, bahkan karena hal tersebut ada juga peternak yang sampai mengalami kebangkrutan. Kebiasaan masyarakat yang lebih menyukai mengkonsumsi susu olahan seperti susu bubuk dan susu kental manis harus mulai diubah menjadi lebih menyukai mengkonsumsi susu segar. Bila usaha tersebut berhasil maka harga susu sapi ditingkat peternak akan meningkat dan membuat peternak mempunyai posisi tawar yang memadai.

Tujuan utama dari suatu usaha peternakan adalah memperoleh keuntungan yang tinggi. Para peternak sapi perah umunya belum melakukan analisis pendapatan dengan baik. Akibatnya pendapatan yang diperoleh dari usaha tersebut masih berupa pendapatan kotor karena semua biaya-biaya produksi yang dikeluarkan belum dihitung, misalnya: penyusutan peralatan, tenaga kerja, dan penyusutan kandang, namun terkadang peternak menjadi tidak mengetahui jika usahanya mengalami kerugian.

Analisis pendapatan merupakan salah satu cara untuk mengetahui jumlah pendapatan bersih yang diperoleh suatu usaha peternakan. Cara tersebut memudahkan peternak mengelola usahanya dan memecahkan permasalahan yang dihadapi. Analisis pendapatan bisa digunakan peternak yang sedang mengalami keuntungan untuk melakukan pengembangan usaha, dan ketika peternak mengalami kerugian, sehingga 
peternak bisa mengetahui penyebabnya dan mampu memecahkan permasalahan tersebut sehingga bisa meraih keuntungan kembali.

\section{METODE}

Penelitian dilakukan pada peternak sapi perah laktasi di Desa Minggirsari Kecamatan Kanigoro Kabupaten Blitar dengan populasi sapi perah minimal 3-5 ekor atau 3-5 ST. Populasi sapi perah laktasi yang dijadikan sampel adalah sapi yang dimiliki peternak minimal 3 ekor atau 3 ST sapi perah laktasi.

Berdasarkan data dari dinas peternakan Kabupeten Blitar pada tahun 2011, populasi sapi perah di Kecamatan Kanigoro sebanyak 1.244 ekor. Populasi sapi perah di Kecamatan Kanigoro menempati urutan keempat terbanyak diantara 22 kecamatan di Kabupaten Blitar.

Metode penelitian yang digunakan adalah metode deskriptif kualitatif dalam bentuk studi kasus (case studies) (Bungin, 2008). Deskriptif kualitatif pada umumnya dilakukan pada penelitian dalam bentuk studi kasus.

Pemilihan lokasi penelitian dilakukan dengan teknik purposive sampling (sengaja) yaitu berdasarkan pada ciri-ciri atau sifat-sifat tertentu yang ada dalam populasi yang sudah diketahui sebelumnya (Achmadi dan Narbuko, 2003). Lokasi tersebut dipilih karena memiliki peternak sapi perah dengan populasi yang cukup banyak. Sampel yang digunakan pada penelitian ini yaitu peternak sapi perah di Desa Minggirsari dengan populasi sapi perah laktasi minimal 3 ekor atau 3 ST. Menurut Zandos (2011), penentuan responden peternak dilakukan secara stratified random sampling yang stratifikasinya dilakukan berdasarkan jumlah kepemilikan induk sapi perah laktasi. Stratifikasi responden peternak sapi perah di Desa Minggirsari dapat dibagi dalam tiga strata yaitu: strata I dengan kepemilikan induk laktasi 1-4 ekor, strata 2 dengan kepemilikan induk laktasi 5-8 ekor dan strata III dengan kepemilikan induk 9-18 ekor. Pembagian strata tersebut bermanfaat umtuk mempermudah perihitungan pendapatan dari responden berdasarkan skala usaha kepemilikan ternak sapi perah laktasi.

Metode pengumpulan data pada penelitian ini dilakukan dengan melakukan survei, wawancara dengan daftar pertanyaan, dan observasi (pengamatan).

\section{METODE ANALISIS}

Data-data yang sudah terkumpul dari penelitian ini dianalisis dengan metode analisis deskriptif dengan tujuam memecahkan masalah secara sistematis dan faktual mengenai fakta-fakta dan sifat-sifat populasi. Analisis perhitungan dilakukan dengan menggunakan perhitungan matematis. Rumus-rumus perhitungan matematis yang digunakan pada penelitian ini adalah sebagai berikut: 
1. Biaya penyusutan (Hartono dan Rahardi, 2003)

$$
\text { Penyusutan }=\frac{\text { Harga beli }- \text { nilai sisa }}{\text { Umur ekonomis }}
$$

2. Biaya total (Firdaus, 2010)

$\mathrm{TC}=\mathrm{TFC}+\mathrm{TVC}$

Keterangan :

$\mathrm{TC}=$ biaya total

$\mathrm{TFC}=$ total biaya tetap

$\mathrm{TVC}=$ total biaya variabel

3. Penerimaan (Firdaus, 2010)

$\mathrm{TR}=\mathrm{P} \times \mathrm{Q}$

Keterangan :

$\mathrm{TR}=$ total penerimaan

$P$ = harga jual

$\mathrm{Q}=$ jumah unit yang dijual

4. Keuntungan (Firman, 2010)

$\pi=\mathrm{TR}-\mathrm{TC}$

Keterangan :

$\pi=$ keuntungan

$\mathrm{TR}=$ total penerimaan

$\mathrm{TC}=$ total biaya

5. Break even point (Hartono dan Rahardi, 2003)

$\begin{array}{ll}\text { BEP Produksi } & =\frac{\text { Total biaya }}{\text { Harga penjualan }} \\ \text { BEP Harga } & =\frac{\text { Total biaya }}{\text { Produksi }}\end{array}$

6. Return cost ratio (Hartono dan Rahardi, 2003)

$$
\mathrm{R} / \mathrm{C}=\frac{\text { Total Penerimaan Penjualan Produk }}{\text { Total Biaya }}
$$

7. Benefit cost ratio (Hartono dan Rahardi, 2003)

$$
\mathrm{B} / \mathrm{C}=\frac{\text { Tingkat Keuntungan }}{\text { Total Biaya }}
$$




\section{HASIL DAN BAHASAN}

\section{Karakteristik Peternak Sapi Perah}

Pemilik ternak sapi perah di Desa Minggirsari mempunyai sapi perah dengan jumlah yang bervariasi. Dilihat dari jumlah induk laktasi yang dimiliki pemilik ternak sapi perah bisa dibagi menjadi tiga strata yaitu strata I (1-4 induk laktasi ), strata II (5-8 induk laktasi ), dan strata III (9-18 induk laktasi).

Tabel 1. Pemilik Ternak Sapi Perah

\begin{tabular}{|l|l|l|l|l|}
\hline No. & Strata & Jumlah (Orang) & Rata-Rata (Ekor) & Rata-Rata (ST) \\
\hline 1 & Strata I & 21 & 5,66 & 4,40 \\
\hline 2 & Strata II & 6 & 10,50 & 7,58 \\
\hline 3 & Strata III & 3 & 23,00 & 17,83 \\
\hline Total & 30 & 8,37 & 6,38 \\
\hline
\end{tabular}

Tabel 1 menunjukkan bahwa pemilik ternak sapi perah di desa tersebut sebanyak 21 orang masuk strata I, 6 orang masuk strata II, dan 3 orang masuk strata III. Rata-rata pemilik ternak sapi perah di desa tersebut mempunyai sapi perah sebanyak 8,37 ekor $(6,38$ ST).

\section{Kepemilikan Ternak Sapi Perah}

Kepemilikan ternak sapi perah di Desa Minggirsari bervariasi dari segi jumlah maupun komposisinya. Hasil penelitian menunjukkan bahwa populasi sapi perah yang dimiliki peternak di Desa Minggirsari sebanyak 251 ekor atau dalam satuan ternak sebanyak 191,30 ST.

Tabel 2. Kepemilikan Ternak Sapi Perah

\begin{tabular}{|c|c|c|c|c|c|c|c|c|c|c|}
\hline \multirow[b]{2}{*}{ No. } & \multirow{2}{*}{$\begin{array}{l}\text { Kepemilika } \\
\text { n Ternak }\end{array}$} & \multicolumn{3}{|c|}{ Strata I } & \multicolumn{3}{|c|}{ Strata II } & \multicolumn{3}{|c|}{ Strata III } \\
\hline & & Ekor & $\mathrm{ST}$ & $\%$ & $\begin{array}{l}\text { Eko } \\
\text { r }\end{array}$ & ST & $\%$ & Ekor & $\mathrm{ST}$ & $\%$ \\
\hline 1 & PD & 24 & 6,0 & 20 & 20 & 5,0 & 32 & 14 & 3,50 & 20 \\
\hline 2 & $\mathrm{D}$ & 17 & 8,5 & 14 & 5 & 2,5 & 8 & 10 & 5,0 & 15 \\
\hline 3 & IL & 57 & 57,0 & 48 & 34 & 34,0 & 54 & 38 & 38,0 & 55 \\
\hline 4 & IK & 19 & 19,0 & 16 & 4 & 4,0 & 6 & 5 & 5,0 & 7 \\
\hline 5 & PJ & 2 & 2,0 & 2 & 0 & 0 & 0 & 2 & 2,0 & 3 \\
\hline & Total & 119 & 92,5 & $\begin{array}{l}10 \\
0\end{array}$ & 63 & 45,5 & $\begin{array}{l}10 \\
0\end{array}$ & 69 & 53,5 & 100 \\
\hline
\end{tabular}


Keterangan :
$\mathrm{PD} \quad=$ Pedet
IL $\quad=$ Induk Laktasi
PJ $\quad=$ Pejantan
$\mathrm{D} \quad=$ Dara
IK $\quad=$ Induk Kering
ST $\quad=$ Satuan Ternak

Tabel 2 menunjukkan bahwa persentase terbanyak kepemilikan sapi perah di Desa Minggirsari adalah induk laktasi sebanyak $48 \%$ (starata I), $54 \%$ (strata II), dan $55 \%$ (strata III). Sedangkan persentase terkecil kepemilikan sapi perah di Desa Minggirsari yaitu pejantan sebesar $2 \%$ (strata I ) dan $3 \%$ (strata III). Sapi pejantan tidak banyak dipelihara peternak di desa tersebut karena sudah menggunakan perkawinan dengan cara inseminasi buatan (IB).

Dilihat dari jumlah rata-rata sapi perah yang dimiliki peternak di Desa Minggirsari maka usaha peternakan sapi perah di Desa Minggirsari termasuk peternakan rakyat. Hal ini sesuai dengan pendapat Ismail (2011) yang menyatakan bahwa usaha ternak sapi perah rakyat memiliki maksimal 10 ekor sapi perah laktasi atau kurang dari 20 ekor sapi perah campuran.

Jenis sapi perah yang dipelihara peternak di Desa Minggirsari adalah sapi perah PFH. Hal ini sesuai dengan pendapat Rahmatullah (2009) yang menyatakan bahwa pada umumnya sapi perah yang ada di Indonesia adalah PFH. Jenis sapi perah PFH dipilih karena sifatnya jinak, mudah beradaptasi, dan produksi susunya baik meskipun lebih rendah dari sapi perah FH asli.

Dari hasil penelitian menunjukkan bahwa sebagian besar tipe usaha peternakan sapi perah di Desa Minggirsari adalah usaha sambilan atau sampingan. Hal ini sesuai dengan pendapat Hartono dan Rahardi (2003) yang menyatakan bahwa usaha ternak dapat dikelola secara sambilan. Tipe usaha ini dipilih karena bertujuan untuk meningkatkan pendapatan keluarga dan memiliki pekerjaan selain beternak sapi perah seperti petani, karyawan dan pedagang.

\section{Analisa Usaha peternakan Sapi Perah Modal}

Modal mempunyai peran penting bagi kelangsungan dan pengembangan suatu usaha yang dijalankan. Dari hasil penelitian, modal yang digunakan peternak sapi perah di Desa Minggirsari berasal dari sumber sendiri (intern). Hal ini sesuai dengan pendapat Apriyono (2009) yang menyatakan bahwa modal yang berasal dari sumber intern adalah modal atau dana yang dibentuk atau dihasilkan sendiri dari dalam perusahaan. Alasan peternak tersebut memilih modal sendiri (intern) daripada modal dari luar (ekstern) yaitu tidak punya kewajiban membayar hutang dan bunga, tidak repot dan setiap saat bisa digunakan ketika membutuhkan. 
Modal diperlukan peternak saat memulai usaha (modal awal) dan saat usaha sudah berjalan (biaya operasional). Dalam usaha peternakan sapi perah di desa tersebut modal awal digunakan untuk membangun kandang, membeli bibit, membeli peralatan, dan menyewa lahan. Saat usaha sudah berjalan modal digunakan peternak antara lain untuk membeli pakan, membayar IB dan membayar listrik. Modal awal yang digunakan responden pada usaha peternakan sapi perah laktasi di Desa Minggirsari rata-rata sebesar Rp 69.246.100.

Tabel 3. Modal Awal Usaha Peternakan Sapi Perah Laktasi

\begin{tabular}{|l|l|l|l|l|l|l|l|}
\hline \multirow{2}{*}{ No. } & \multirow{2}{*}{ Uraian } & \multicolumn{2}{|c|}{ Strata I } & \multicolumn{2}{c|}{ Strata II } & \multicolumn{2}{c|}{ Strata III } \\
\cline { 2 - 8 } & & Rp. & $\%$ & Rp. & $\%$ & \multicolumn{1}{l}{ Rp. } & $\%$ \\
\hline 1 & Ternak & 36.190 .400 & 73 & 63.333 .300 & 77 & 143.333 .000 & 78 \\
\hline 2 & Kandang & 5.666 .600 & 12 & 11.000 .000 & 13 & 24.000 .000 & 13 \\
\hline 3 & Peralatan & 7.063 .600 & 14 & 7.819 .100 & 9 & 14.214 .000 & 8 \\
\hline 4 & Sewa Lahan & 335.700 & 1 & 466.600 & 1 & 883.000 & 1 \\
\hline \multicolumn{2}{|l|}{ Total } & 49.255 .900 & 100 & 82.619 .000 & 100 & 182.430 .000 & 100 \\
\hline
\end{tabular}

Tabel 3 menunjukkan bahwa persentase modal awal terbesar pada usaha peternakan sapi perah laktasi di Desa Minggirsari digunakan untuk membeli ternak sebanyak $73 \%$ (strata I), $77 \%$ (strata II), dan 78 \% (strata III). Pada strata I modal awal untuk membeli peralatan sebanyak $14 \%$ memiliki persentase terbesar dibandingkan dengan strata lainnya. Hal ini memperlihatkan bahwa semakin besar skala usaha maka persentase modal awal peralatan semakin kecil.

\section{Biaya (cost)}

Biaya usaha peternakan sapi perah laktasi di Desa Minggirsari terdiri dari 3 macam yaitu biaya tetap (fixed cost), biaya tidak tetap (variable cost) dan biaya total (total cost).

\section{a. Biaya Tetap}

Biaya tetap merupakan biaya yang tidak terpengaruh oleh naik turunnya kegiatan produksi usaha peternakan dan harus tetap dikeluarkan meskipun tidak ada kegiatan produksi. Contoh biaya tetap usaha peternakan sapi perah laktasi di Desa Minggirsari yaitu penyusutan ternak, penyusutan peralatan, penyusutan kandang dan sewa lahan. Biaya tetap yang dikeluarkan responden rata-rata sebesar Rp 8.141.100/tahun.

Tabel 4. Biaya Tetap Usaha Peternakan Sapi Perah Laktasi (Rp/Tahun)

\begin{tabular}{|l|l|l|l|l|l|l|l|}
\hline \multirow{2}{*}{ No. } & \multirow{2}{*}{ Uraian } & \multicolumn{2}{|c|}{ Strata I } & \multicolumn{3}{c|}{ Strata II } & \multicolumn{2}{c|}{ Strata III } \\
\cline { 3 - 8 } & & $\mathrm{Rp}$ & $\mathrm{Rp}$ & $\%$ & $\mathrm{Rp}$ & $\%$ \\
\hline
\end{tabular}




\begin{tabular}{|l|l|l|l|l|l|l|l|}
1 & P.Ternak & 4.523 .800 & 77,7 & 7.916 .700 & 81,6 & 17.916 .800 & 83,7 \\
\hline 2 & P.Kandang & 283.400 & 4,8 & 550.000 & 5,7 & 1.200 .000 & 5,6 \\
\hline 3 & P.Peralatan & 657.000 & 11,3 & 766.800 & 7,9 & 1.411 .700 & 6,6 \\
\hline 4 & Sewa Lahan & 335.700 & 6,2 & 466.700 & 4,8 & 883.300 & 4,1 \\
\hline \multicolumn{2}{|l}{ Total } & 5.799 .900 & 100,0 & 9.699 .300 & 100,0 & 21.411 .700 & 100,0 \\
\hline
\end{tabular}

Tabel 4 menunjukkan bahwa biaya tetap terbanyak pada usaha peternakan sapi perah laktasi di Desa Minggirsari yang dikeluarkan peternak berasal dari penyusutan ternak dengan persentase sebesar 77,7 \% (strata I), 81,6\% (strata II), dan 83,7 \% (strata III). Biaya penyusutan peralatan pada strata I sebesar $11,3 \%$ lebih besar dari strata lainnya karena skala usahanya lebih kecil dari pada strata lainnya.

Bibit yang digunakan pada usaha peternakan sapi perah laktasi di Desa Minggirsari berupa dara bunting \pm 7 bulan dan induk yang sudah beranak 1 atau 2 kali tergantung kemampuan keuangan peternak dengan masa produksi sekitar 8 tahun . Peralatanperalatan yang digunakan untuk kegiatan usaha antara lain Gerobak, Timba, Sepeda Motor, Sabit dan Sekrop.

\section{a. Biaya Tidak Tetap (variabel cost)}

Biaya tidak tetap merupakan biaya yang tergantung pada jumlah produksi dan harga yang berlaku pada waktu tersebut. Biaya tidak tetap yang dikeluarkan responden pada usaha peternakan tersebut rata-rata sebesar Rp 44.793.500/tahun.

Tabel 5. Biaya Tidak Tetap Usaha Peternakan Sapi Perah Laktasi

\begin{tabular}{|c|c|c|c|c|c|c|c|}
\hline \multirow{2}{*}{ No } & \multirow{2}{*}{ Uraian } & \multicolumn{2}{|l|}{ Strata I } & \multicolumn{2}{|l|}{ Strata II } & \multicolumn{2}{|l|}{ Strata III } \\
\hline & & $\mathrm{Rp}$ & $\%$ & $\mathrm{Rp}$ & $\%$ & $\mathrm{Rp}$ & $\%$ \\
\hline 1 & Pakan & $\begin{array}{l}25.403 .00 \\
0\end{array}$ & 82,0 & 44.922 .900 & 86,1 & $\begin{array}{l}109.723 .20 \\
0\end{array}$ & 86,7 \\
\hline 2 & $\mathrm{IB}+\mathrm{PKB}$ & 350.000 & 1,1 & 553.300 & 1,1 & 1.361 .700 & 1,1 \\
\hline 3 & K. Ternak & 233.300 & 0,7 & 358.300 & 0,7 & 666.600 & 0,5 \\
\hline 4 & $\begin{array}{l}\text { Transportas } \\
\text { i }\end{array}$ & 600.000 & 1,9 & 1.030 .000 & 2,0 & 2.440 .000 & 1,9 \\
\hline 5 & Listrik & 600.000 & 1,9 & 700.000 & 1,3 & 1.040 .000 & 0,8 \\
\hline 6 & Margarin & 92.900 & 0,3 & 114.000 & 0,2 & 192.000 & 0,2 \\
\hline 7 & $\begin{array}{l}\text { Tenaga } \\
\text { Kerja }\end{array}$ & 3.714 .300 & 12,0 & 4.500 .000 & 8,6 & 11.200 .000 & 8,8 \\
\hline & Total & $\begin{array}{l}30.993 .50 \\
0\end{array}$ & 100,0 & $\begin{array}{l}52.178 .50 \\
0 \\
\end{array}$ & $\begin{array}{l}100, \\
0 \\
\end{array}$ & 126.623 .500 & 100,0 \\
\hline
\end{tabular}


Tabel 5 menunjukkan bahwa persentase biaya tidak tetap terbesar pada usaha peternakan sapi perah laktasi di Desa Minggirsari yaitu pakan sebesar 82,0 \% (strata I), $86,1 \%$ (strata II), dan 86,7 \% (strata III).

Contoh-contoh biaya tidak tetap usaha peternakan sapi perah laktasi di Desa Minggirsari adalah sebagai berikut :

1. Pakan

Pakan yang diberikan peternak pada sapi perah laktasi terdiri dari hijauan, konsentrat dan pakan tambahan (feed additive). Hal ini sesuai dengan pendapat Anonimous (2004) yang menyatakan bahwa makanan sapi perah dapat dikelompokkan menjadi tiga kelompok yakni makanan hijauan, konsentrat dan makanan tambahan. Jenis hijauan makanan ternak (HMT) utama yang digunakan adalah Rumput Gajah (Pannisetum purpureum). Selain itu, hijauan yang digunakan peternak tersebut antara lain Jagung (Zea mays), Jerami Padi (Oryza sativa) dan Rumput Lapangan. Jumlah pemberian hijauan sekitar 30-40 kg per hari. Hijauan yang digunakan responden berasal dari lahan milik sendiri, menyewa lahan, mengarit dan membeli dengan sistem tebas. Biaya hjiauan berasal dari biaya sewa lahan HMT, pemeliharaan HMT, dan membeli HMT. Biaya sewa lahan HMT di Desa Minggirsari berkisar antara Rp 10.000.000-Rp 14.000.000/ha/tahun. Untuk biaya pemeliharaan HMT di desa tersebut berkisar antara Rp. 350.000-Rp. 2.500.000/tahun. Bila membeli HMT dengan sistem tebas berkisar antara $\mathrm{Rp} \mathrm{4.200.000-Rp} \mathrm{6.300.000/ha/potong.} \mathrm{Biaya} \mathrm{rata-rata} \mathrm{hijauan}$ pada usaha peternakan sapi perah laktasi di Desa Minggirsari sebesar $\mathrm{Rp}$ 6.386.100/tahun. Peternak dapat menghemat biaya hijauan bila menyewa lahan daripada membeli hijauan dengan sistem tebas.

Konsentrat yang digunakan peternak di Desa Minggirsari antara lain terdiri dari pakan jadi, bungkil kelapa, bekatul, tepung kedelai, dan onggok (gamblong). Biaya konsentrat sapi perah laktasi di desa tersebut sekitar Rp 14.000-Rp 24.000/hari. Biaya rata-rata konsentrat pada usaha peternakan sapi perah laktasi di Desa Minggirsari yaitu sebesar Rp 30.718.600/tahun. Untuk pakan tambahan (feed additive) yang digunakan peternak tersebut terdiri dari garam dan mineral buatan pabrik. Biaya rata-rata mineral pada usaha peternakan sapi perah laktasi di Desa Minggirsari yaitu sebesar Rp 634.200/tahun.

2. Inseminasi buatan (IB) dan pemeriksaan kebuntingan (PKB)

Biaya inseminasi buatan (IB) di Desa Minggirsari berkisar per IB berkisar antara Rp 40.000-Rp 50.000 dan biaya PKB sebesar RP 15.000/PKB. Umumnya sapi perah di desa tersebut berhasil bunting setelah di IB sebanyak 1-3 kali. Biaya rata-rata IB dan PKB pada usaha peternakan sapi perah laktasi di Desa Minggirsari yaitu sebesar Rp 491.800/tahun.

3. Kesehatan ternak 
Untuk mencapai produksi susu yang baik maka kesehatan ternak tersebut harus diperhatikan. Kegiatan pencegahan penyakit harus dilakukan sebaik mungkin agar dapat mengurangi biaya pengobatan. Biaya rata-rata kesehatan ternak pada usaha peternakan sapi perah laktasi di Desa Minggirsari yaitu sebesar Rp 301.600/tahun.

4. Transportasi

Biaya transportasi pada usaha peternakan sapi perah tersebut berasal dari biaya perawatan kendaraan dan biaya bahan bakar yang umumnya digunakan untuk mengangkut hijauan dari lahan, menyetor susu ke TPS, dan membeli pakan serta peralatan-peralatan yang digunakan. Biaya rata-rata transportasi pada usaha peternakan sapi perah laktasi di Desa Minggirsari yaitu sebesar Rp 870.000/tahun.

5. Listrik

Pada kegiatan usaha peternakan sapi perah laktasi di Desa Minggirsari listrik digunakan untuk penerangan dan menghidupkan pompa air. Biaya rata-rata listrik pada usaha peternakan sapi perah laktasi di Desa Minggirsari yaitu sebesar Rp 664.000/tahun.

6. Margarin

Pada kegiatan usaha peternakan tersebut margarin bermanfaat untuk memudahkan proses pemerahan sapi secara manual karena dapat melicinkan ambing sehingga sapi merasa nyaman saat diperah. Biaya rata-rata margarin pada usaha peternakan sapi perah laktasi di Desa Minggirsari yaitu sebesar Rp 107.000/tahun.

7. Tenaga kerja

Tenaga kerja yang digunakan sebagian besar adalah pemilik ternak tersebut. Biaya rata-rata tenaga kerja pada usaha peternakan sapi perah laktasi di Desa Minggirsari yaitu sebesar Rp 4.620.000/tahun.

\section{b. Biaya total (total cost)}

Biaya total merupakan seluruh biaya yang dikeluarkan baik berupa biaya tetap maupun biaya variabel. Biaya total yang dikeluarkan responden rata-rata sebesar Rp $52.934 .600 /$ tahun .

Tabel 6. Biaya Total Usaha Peternakan Sapi Perah Laktasi

\begin{tabular}{|c|c|c|c|c|c|c|c|}
\hline \multirow{2}{*}{ No } & \multirow{2}{*}{ Uraian } & \multicolumn{2}{|l|}{ Strata I } & \multicolumn{2}{|l|}{ Strata II } & \multicolumn{2}{|l|}{ Strata III } \\
\hline & & $\mathrm{Rp}$ & $\%$ & $\mathrm{Rp}$ & $\%$ & $\mathrm{Rp}$ & $\%$ \\
\hline 1 & B. Tetap & 5.799 .900 & 15,8 & 9.700 .200 & 15,7 & 21.411 .700 & 14,5 \\
\hline 2 & B. Variabel & 30.993 .500 & 84,2 & 52.178 .500 & 84,3 & 126.623 .500 & 85,5 \\
\hline & Total & 36.793 .400 & 100,0 & 61.878 .700 & 100,0 & 148.035 .200 & 100,0 \\
\hline
\end{tabular}

Tabel 6 menunjukkan bahwa berdasarkan biaya total pada usaha peternakan sapi perah laktasi di Desa Minggirsari, jumlah biaya tetap pada strata I dengan persentase 15,8 $\%$ lebih besar dari pada strata lainnya karena skala usahannya lebih kecil. 
Pada usaha peternakan sapi perah laktasi di Desa Minggirsari biaya terbesar yang dikeluarkan responden dari seluruh biaya produksi yaitu biaya pakan dengan persentase sebesar 71,29 \%. Hal ini sesuai dengan pendapat Makin (2011) yang menyatakan bahwa ongkos makanan di Indonesia mencapai 60-80 \% dari biaya produksi. Selain sebagai biaya terbesar dari seluruh biaya produksi, pakan merupakan faktor yang berpengaruh terhadap produktifitas ternak. Jadi pakan harus mendapatkan perhatian serius dari peternak agar sapi perah yang dipelihara bisa berproduksi tinggi dengan biaya yang ekonomis sehingga peternak tetap bisa meraih keuntungan.

\section{Penerimaan (revenue)}

Penerimaan pada usaha sapi perah laktasi di Desa Minggirsari berasal dari beberapa sumber yaitu penjualan susu, penjualan pedet, dan penjualan ternak afkir. Hal ini tidak sesuai dengan pendapat Mastuti dan Hidayat (2008) yang menyatakan bahwa penerimaan pada usaha sapi perah berasal dari beberapa komponen diantaranya adalah penjualan produk utama yaitu susu dan produk sampingan yaitu penjualan ternak (pedet jantan dan ternak afkir), kenaikan nilai ternak (bila pedet tidak dijual) dan penjualan pupuk. Pupuk kandang tidak dijual oleh peternak sapi perah di desa tersebut karena digunakan sendiri untuk pemupukan pada lahan pertanian dan lahan hijauan makanan ternak. Kotoran ternak merupakan limbah usaha peternakan sapi perah sebagai bahan pupuk kandang yang dapat dijadikan sumber penerimaan usaha. Jika dijual, limbah tersebut dapat menambah penerimaan sekitar Rp. 200.000/ST/tahun. Pedet yang dijual responden tidak hanya pedet jantan tetapi juga pedet betina. Hal tersebut dilakukan karena adanya kebutuhan mendesak dan memelihara pedet dianggap kurang menguntungkan.

Jumlah penerimaan peternak tergantung pada harga dan jumlah produk yang dijual. Sumber penerimaan utama pada usaha peternakan sapi perah laktasi adalah penjualan susu. Harga susu sapi di tingkat peternak berkisar antara Rp. 3.250-Rp. 3.450/liter. Terjadinya perbedaan harga susu tersebut disebabkan adanya perbedaan tempat menjual susu. Adanya kenaikan harga sapi potong berdampak positif terhadap meningkatnya harga pedet dan harga sapi perah afkir. Harga pedet berumur \pm 1 bulan di desa tersebut sekitar Rp. 1.000.000/ekor dan harga sapi perah afkir sekitar Rp. 6.000.000/ekor. Penerimaan rata-rata yang diperoleh responden sebesar Rp. 56.069.700/tahun. 
Tabel 7. Penerimaan Usaha Peternakan Sapi Perah Laktasi

\begin{tabular}{|l|l|l|l|l|l|l|l|}
\hline \multirow{2}{*}{ No. } & \multirow{2}{*}{ Uraian } & \multicolumn{2}{|c|}{ Strata I } & \multicolumn{2}{c|}{ Strata II } & \multicolumn{2}{c|}{ Strata III } \\
\cline { 3 - 8 } & & $\mathrm{Rp}$ & $\%$ & $\mathrm{Rp}$ & $\%$ & $\mathrm{Rp}$ & $\%$ \\
\hline 1 & P.Susu & 31.493 .400 & 81,7 & 53.694 .500 & 81,3 & 130.803 .800 & 82,4 \\
\hline 2 & P. Pedet & 3.619 .000 & 9,4 & 6.333 .300 & 9,6 & 14.333 .300 & 9,0 \\
\hline 3 & P. Sapi Afkir & 2.714 .300 & 7,0 & 4.750 .000 & 7,2 & 10.750 .000 & 6,8 \\
\hline 4 & P.Limbah & 723.800 & 1,9 & 1.266 .700 & 1,9 & 2.866 .700 & 1,8 \\
\hline \multicolumn{2}{|c|}{ Total } & 38.550 .500 & 100,0 & 66.044 .500 & 100,0 & 158.753 .800 & 100,0 \\
\hline
\end{tabular}

Tabel 7 menunjukkan bahwa penerimaan terbesar pada usaha peternakan sapi perah laktasi di Desa Minggirsari berasal dari penjualan susu dengan persentase sebesar $81,7 \%$ (strata I), 81,3 \% (strata II), dan 82,4 \% (strata III). Pada strata III jumlah penerimaan yang diperoleh lebih besar dari strata lainnya karena jumlah induk sapi perah yang dipelihara lebih banyak.

\section{Keuntungan}

Tujuan dari mendirikan suatu usaha peternakan sapi perah laktasi adalah untuk mendapatkan keuntungan yang tinggi. Keuntungan merupakan hasil dari total penerimaan yang berasal dari penjualan produk dikurangi dengan total biaya yang dikeluarkan. Hasil penelitian menunjukkan bahwa secara umum usaha peternakan sapi perah laktasi di Desa Minggirsari termasuk usaha yang menguntungkan. Keuntungan yang diperoleh responden rata-rata sebesar Rp. 3.135.100/tahun.

Tabel 8. Keuntungan Usaha Peternakan Sapi Perah Laktasi

\begin{tabular}{|l|l|l|l|l|}
\hline No. & \multicolumn{1}{|c|}{ Uraian } & Strata I (Rp) & Strata II (Rp) & Strata III (Rp) \\
\hline 1 & Total Penerimaan & 38.550 .500 & 66.044 .500 & 158.753 .800 \\
\hline 2 & Total Biaya & 36.793 .400 & 61.878 .700 & 148.035 .200 \\
\hline \multicolumn{2}{|c|}{ Keuntungan } & 1.757 .100 & 4.165 .800 & 10.718 .600 \\
\hline
\end{tabular}

Tabel 8 menunjukkan bahwa keuntungan terbesar pada usaha peternakan sapi perah laktasi di Desa Minggirsari terdapat pada strata III yaitu sebesar Rp. 10.718.600/tahun. Hal ini memperlihatkan bahwa semakin banyak induk sapi perah yang dipelihara maka keuntungan yang diperoleh akan semakin banyak.

Agar usaha peternakan sapi perah laktasi bisa memproleh keuntungan yang optimal salah satu hal yang harus diperhatikan adalah perbandingan antara sapi produktif (sapi laktasi dan sapi kering kandang) dengan sapi non produktif (pejantan, dara, dan pedet) dan perbandingan antara sapi laktasi dengan sapi kering kandang. Perbandingan 
antara sapi produktif dengan sapi non produktif di lokasi penelitian yaitu 62,55\% sapi produktif dan $37,45 \%$ sapi non produktif. Sedangkan perbandingan antara sapi laktasi dengan sapi kering kandang yaitu 82,17 \% sapi laktasi dan 17,83 \% sapi kering kandang. Hal ini tidak sesuai dengan pendapat Makin (2011) yang menyatakan bahwa perbandingan antara jumlah sapi produktif dengan sapi non produktif yang optimum yaitu $70 \%$ sapi produktif dan $30 \%$ sapi non produktif serta perbandingan sapi laktasi dengan sapi kering kandang yang optimum yaitu $85 \%$ berbanding dengan $15 \%$.

\section{Break Event Point (BEP)}

BEP merupakan keadaan dimana suatu usaha yang dikukan mencapai titik impas tidak mendapatkan keuntungan dan tidak mengalami kerugian berdasarkan harga jual produk serta tingkat produksi yang dihasilkan. Dari hasil penelitian menunjukkan bahwa BEP harga rata-rata pada usaha peternakan sapi perah laktasi di Desa Minggirsari yaitu Rp. 3.809/liter dan BEP produksi yaitu 16.129 liter/tahun. Artinya usaha peternakan sapi perah laktasi di Desa Minggirsari berdasarkan harga susu mencapai titik impas saat harga susu sebesar Rp. 3.809/liter dan berdasarkan produksi susu usaha peternakan tersebut mencapai titik impas ketika produksi susu yang dihasilkan sebanyak 16.129 liter/tahun.

Tabel 9. Break Even Point (BEP) Usaha Peternakan Sapi Perah Laktasi

\begin{tabular}{|l|l|l|l|}
\hline \multirow{2}{*}{ No. } & \multirow{2}{*}{ Strata } & BEP & \multicolumn{2}{|l|}{} \\
\cline { 3 - 4 } & & Harga $(\mathrm{Rp} / \mathrm{ltr})$ & Produksi $(\mathrm{ltr} / \mathrm{thn})$ \\
\hline 1 & Strata I & 3.804 & 11.310 \\
\hline 2 & Strata II & 3.851 & 18.601 \\
\hline 3 & Strata III & 3.759 & 44.919 \\
\hline
\end{tabular}

Tabel 9 menunjukkan bahwa BEP harga terendah pada usaha peternakan sapi perah laktasi di Desa Minggirsari terdapat pada strata III yaitu sebesar Rp. 3.759/liter. Artinya usaha peternakan sapi perah laktasi di Desa Minggirsari berdasarkan harga susu mencapai titik impas saat harga susu sebesar Rp. 3.759/liter. Hal ini memperlihatkan bahwa semakin besar skala usaha yang dijalankan maka usaha tersebut akan semakin ekonomis.

\section{Kelayakan Usaha}

Analisis kelayakan usaha merupakan upaya untuk megetahui suatu usaha apakah layak atau tidak untuk diusahakan. Suatu usaha bisa dikatakan layak jika dapat memberikan manfaat yang lebih besar jika dibandingkan dengan biaya yang dikeluarkan baik secara finansial maupun non finansial. Hasil analisis ini bermanfaat sebagai bahan 
informasi untuk mengambil keputusan apakah menerima atau menolak suatu gagasan usaha peternakan tersebut.

Dari hasil penelitian menunjukan bahwa usaha peternakan sapi perah laktasi di Desa Minggirsari layak untuk diusahakan. Hal-hal yang dijadikan acuan pada penelitian ini untuk menegetahui kelayakan usaha adalah sebagai berikut :

\section{a. Return Cost Ratio (R/C)}

$\mathrm{R} / \mathrm{C}$ merupakan perbandingan antara penerimaan dengan biaya-biaya yang dikeluarkan pada kegiatan produksi sampai menghasilkan produk. Nilai $\mathrm{R} / \mathrm{C}$ rata-rata pada usaha peternakan sapi perah laktasi di Desa Minggirsari yaitu 1,054 (Lampiran 9). Berdasarkan hasil analisis $\mathrm{R} / \mathrm{C}$ menunjukkan bahwa usaha peternakan tersebut layak diusahakan karena nilai $\mathrm{R} / \mathrm{C}$ sebesar 1,054 > 1. Nilai R/C 1,054 artinya bahwa setiap Rp. 1.000 biaya yang dikeluarkan akan menghasilkan penerimaan sebesar Rp. 1.054. Semakin besar nilai $\mathrm{R} / \mathrm{C}$ maka penerimaan yang diperoleh semakin besar dan usaha tersebut semakin layak untuk diusahakan.

Tabel 10. Kelayakan Usaha Peternakan Sapi Perah Laktasi (R/C)

\begin{tabular}{|l|l|l|}
\hline No. & Strata & R/C \\
\hline 1 & Strata I & 1,047 \\
\hline 2 & Strata II & 1,063 \\
\hline 3 & Strata III & 1,080 \\
\hline
\end{tabular}

Tabel 10 menunjukkan bahwa nilai $\mathrm{R} / \mathrm{C}$ terbaik terdapat pada strata III yaitu sebesar 1,080. Nilai R/C 1,080 artinya bahwa setiap Rp. 1.000 biaya yang dikeluarkan akan menghasilkan penerimaan sebesar Rp. 1.080. Hal ini memperlihatkan bahwa semakin besar skala usaha peternakan sapi perah tersebut maka usaha tersebut semakin layak untuk diusahakan.

\section{b. Benefit Cost Ratio (B/C)}

$\mathrm{B} / \mathrm{C}$ merupakan perbandingan antara tingkat keuntungan dengan seluruh biaya yang dikeluarkan. Nilai B/C rata-rata pada usaha peternakan sapi perah laktasi di Desa Minggirsari yaitu 0,054. Berdasarkan hasil analisis $\mathrm{B} / \mathrm{C}$, menunjukkan bahwa usaha peternakan tersebut layak diusahakan karena nilai $\mathrm{B} / \mathrm{C}$ sebesar $0,054>0$. Nilai B/C 0,033 artinya bahwa setiap Rp. 1.000 biaya yang dikeluarkan akan menghasilkan tambahan keuntungan sebesar Rp. 54. Semakin besar nilai B/C maka keuntungan yang diperoleh semakin besar dan semakin layak untuk diusahakan.

Tabel 11. Kelayakan Usaha Peternakan Sapi Perah Laktasi (B/C) 


\begin{tabular}{|l|l|l|}
\hline No. & Strata & B/C \\
\hline 1 & Strata I & 0,047 \\
\hline 2 & Strata II & 0,060 \\
\hline 3 & Strata III & 0,080 \\
\hline
\end{tabular}

Tabel 11 menunjukkan bahwa nilai B/C terbaik terdapat pada strata III yaitu sebesar 0,080. Nilai B/C 0,080 artinya bahwa setiap Rp. 1.000 biaya yang dikeluarkan akan menghasilkan keuntungan sebesar Rp. 80. Hal ini memperlihatkan bahwa semakin besar skala usaha peternakan sapi perah tersebut maka usaha tersebut semakin layak untuk diusahakan.

\section{SIMPULAN}

Berdasarkan hasil penelitian ini dapat disimpulkan :

1. Biaya total pada usaha peternakan sapi perah laktasi di Desa Minggirsari Kecamatan Kanigoro Kabupaten Blitar yaitu sebesar Rp. 52.934.600/tahun, terdiri dari biaya tetap sebesar Rp. 8.141.100/tahun dan biaya variabel sebesar Rp. 44.793.500/tahun. Pada strata I biaya total usaha peternakan tersebut sebesar Rp. 36.793.400/tahun, strata II sebesar Rp. 61.878.000/tahun, dan strata III sebesar Rp. 148.035.000/tahun.

2. Total penerimaan pada usaha peternakan sapi perah laktasi di Desa Minggirsari Kecamatan Kanigoro Kabupaten Blitar yaitu sebesar Rp. 56.069.700/tahun, terdiri dari penjualan susu sebesar Rp. 45.864.700/tahun, penjualan pedet sebesar Rp. 5.233.300/tahun, penjualan sapi afkir sebesar Rp. 3.925.000/tahun, dan penjualan limbah sebesar Rp. 1.046.700/tahun . Pada strata I total penerimaan pada usaha peternakan tersebut sebesar Rp. 38.550.500/tahun, strata II sebesar Rp. 66.044.500/tahun, dan strata III sebesar Rp. 158.753.800/tahun.

3. Keuntungan pada usaha peternakan sapi perah laktasi di Desa Minggirsari Kecamatan Kanigoro Kabupaten Blitar yaitu sebesar Rp. 3.135.100/tahun. Pada strata I keuntungan usaha peternakan tersebut sebesar Rp. 1.757.500/tahun, strata II sebesar Rp. 4.165.800/tahun, dan strata III sebesar Rp. 10.718.600/tahun. Nilai BEP usaha peternakan tersebut berdasarkan harga susu yaitu Rp. 3.809/liter dan berdasarkan produksi susu yaitu 16.129 liter/tahun. Pada strata I nilai BEP harga yaitu Rp. 3.804/liter dan BEP produksi yaitu 11.310 liter/tahun, strata II nilai BEP harga adalah Rp. 3.851/liter dan BEP produksi adalah 18.601 liter/tahun, dan starata III nilai BEP harga adalah Rp. 3.759/ liter dan BEP produksi adalah 44.919 liter/tahun. Nilai R/C pada usaha peternakan sapi perah tersebut yaitu 1,054 dan nilai $\mathrm{B} / \mathrm{C}$ nya yaitu 0,054 . Pada strata I nilai $\mathrm{R} / \mathrm{C}$ pada usaha peternakan tersebut adalah 1,047 dan nilai $\mathrm{B} / \mathrm{C}$ nya adalah 0,047 , strata II nilai $\mathrm{R} / \mathrm{C}$ nya adalah 1,063 dan nilai $\mathrm{B} / \mathrm{C}$ nya adalah 0,063 , dan strata III nilai $\mathrm{R} / \mathrm{C}$ nya adalah 1,080 dan nilai $\mathrm{B} / \mathrm{C}$ nya adalah 0,080 .

\section{DAFTAR PUSTAKA}

Achmadi, A dan C. Narbuko. 2003. Metodologi Penelitian. Bumi Aksara. Jakarta. 
Anonimous. 2004. Petunjuk Praktis Beternak Sapi Perah. Kanisius. Yogyakarta.

Apriyono, A. 2009. $\quad$ Sumber $\quad$ Modal. http://ilmumanajemen.wordpress.com/2009/01/17/sumber-modal. 25 Pebruari 2012.

Bungin, B. 2008. Penelitian Kualitatif. Kencana Media Group. Jakarta.

Firdaus, M. 2010. Manajemen Agibisnis. Bumi Aksara. Jakarta.

Firman, A. 2010. Agribisnis Sapi Perah Dari Hulu Sampai Hilir. Widya Padjajaran. Bandung.

Gulo, W. 2004. Metodologi Penelitian. Grasindo. Jakarta.

Hartono, R dan F. Rahardi. 2003. Agribisnis Peternakan. Penebar Swadaya. Jakarta.

Ismail, R. 2011. Terminologi DalamPeternakanSapi Perah. http://rismanismail2.wordpress.com/2011/10/09/terminologi-dalam-peternakansapi-perah/

Makin, M. 2011. Tata Laksana Peternakan Sapi Perah. Graha Ilmu. Yogyakarta.

Mastuti, S dan NN Hidayat. 2008. Peranan Tenaga Kerja Perempuan Dalam Usaha Ternak Sapi Perah Di Kabupaten Banyumas. Jurnal Animal Production 11 (1). Hal 40-47. http://Animal production. net/index.php/JAP/article/download/221/220. 2 Maret 2012.

Muharlien, M. E. Sawitri, dan T. E. Susilorini. 2008. Budi Daya 22 Ternak Potensial. Penebar Swadaya. Jakarta.

Nugroho, YI. 2010. Beralih Ke Susu Segar. http: www.agrina-online.com. 2 Pebruari 2011.

. 2011. Rame-Rame Minum Susu Segar. http://www.agrina-online.com. 24 Pebruari 2012.

Rahmatullah, T. 2009. Story Of Sapi Perah PFH. http:/cakangon.blogspot.com/2009/02/story-of-sapiperahpfh.html. Diakses 11 Mei 2011.

Zandos, F. 2011. Strategi Pengembangan Peternakan Sapi Perah Rakyat. http://repository.ipb.ac.id. 24 Juli 2012. 